\title{
Sustainability curriculum in UK university sustainability reports
}

Abstract: One of the major barriers to incorporating sustainability in the HE curriculum is its absence from the university's sustainability strategy, the annual reflection of which is the institution's sustainability report. While strategies stipulate future targets, reports record what has already been achieved in the previous academic year. In that respect, sustainability reports function as internally created reviews of an institution's sustainability activity. Various reviews of sustainability curriculum have taken place in the UK HE sector. This is the first effort to explore sustainability curriculum provision exclusively through HEls' sustainability reports. The sample consists of the most recent, whole-institution sustainability reports issued by UK HEIs in the past five years. An exploratory content analysis identified the reports' sustainability curriculum coverage patterns. The findings suggest that UK universities are widely heterogeneous in their sustainability curriculum reporting practices. Of the universities that have issued a whole-institution sustainability report in the past five years, $37 \%$ cover their sustainability curriculum provision in a comprehensive way, in their reports. These findings might be of interest to sustainability professionals in the reporting or the curriculum provision end. The study hopes to encourage wider coverage of the sustainability curriculum provision in universities' wholeinstitution sustainability reports.

Keywords: sustainability reporting, sustainability curriculum, sustainability in higher education (SHE)

Katerina Kosta

Oxford Brookes University, Faculty of Humanities and Social Sciences

Headington Campus, OX3 OBP, Oxford, UK

katerina.kosta-2016@brookes.ac.uk

\section{Introduction}

While many universities have made impressive progress with regard to greening their campuses, embedding sustainability in the curriculum is often seen as a harder challenge (Ryan and Cotton 2013; Sterling 2012; Tilbury and Ryan 2011). Various barriers have been identified to implementing sustainability in the curriculum with an important one being its absence from the institution's strategy. Strategies set forth the agenda of each institution. It is likely that sustainability curriculum will be prioritised and promoted, if included in the institutional strategy. Being mostly future oriented, strategies contain projected aims and goals while the reflection of an institution's sustainability strategy each year is the annual sustainability report, which describes not what might happen in the future but has already been achieved. In that respect, sustainability reports function as internally created reviews of an institution's sustainability activity.

Reporting on universities' sustainability curriculum provision seems to be in high demand by various UK HE stakeholders. The majority of students believe that 'sustainable development is something which university courses should actively incorporate and promote' (Drayson and Taylor 2015: 634). Reporting on an institutions' sustainability curriculum provision may thus improve the student experience of these literal shareholders of universities since the 
tripling of their tuition fees. Moreover, the People and Planet University League, an influential environmental performance ranking of UK universities, includes heavily weighted indicators for reporting on sustainability curriculum provision. Including a curriculum provision baseline in the institution's sustainability report may thus contribute to outside stakeholders' better tracking of a university's ESD performance. In Wales, sustainability curriculum reporting was a government requirement, which supports the institutionalisation of sustainability in higher education (Glover et al 2011). In the rest of the UK, the Quality Assurance Agency (QAA) for higher education has complemented its quality audits with an ESD component (QAA 2014). Thus, recording sustainability curriculum provision in an institution's sustainability report might meet the needs of multiple internal and external stakeholders.

However, sustainability reports are an emerging tool for the promotion of university sustainability (White 2014) and there is limited guidance on the format and content of the reports. Of the existing guidelines, the Sustainability Tracking Assessment and rating System (STARS) ${ }^{1}$ is one of the most systematic and complete. STARS recommends reporting all 'sustainability courses' and 'courses that include sustainability' giving numbers, titles and content descriptors (STARS 2016: 31). It is stated that conducting an inventory of academic offerings provides an important foundation for advancing sustainability in the curriculum. While STARS originated from and mainly provides for the American HE sector, the Learning in Future Environments (LiFE) index by the EAUC is a broadly used self-assessment and reporting system in the UK. LiFE recommends that ESD curriculum provision is embedded within the institutions' sustainability strategy ${ }^{2}$ while being routinely monitored and evaluated. Some guidelines on Sustainability Reporting have also been issued by the Green Gown Awards which recognise excellent sustainability performance within tertiary education and which have recently introduced a new Sustainability Reporting ${ }^{3}$ category. Monitoring sustainability performance in core functions of an organisation is recommended. The core function of universities is education and sustainability education is according to HEFCE 'the greatest contribution HE can make to sustainable development' (HEFCE 2014). As a consequence, sustainability education and the taught curriculum are expected to be a basic component of university sustainability reporting (Ceulemans et al 2015b; Fischer et al 2015). The recommendation of comprehensive reporting of an institution's sustainability curriculum, by leading SHE consultancies (AASHE, EAUC) is coupled with the importance of the principle of materiality for sustainability reporting (PWC 2016; KPMG 2012; GRI 2015). In response, the current study explores how universities include the material aspect of sustainability curriculum in their sustainability reports. This topic will be explored by answering three research questions:

1. What percentage of UK universities publishes a whole-institution sustainability report?

2. What is the up-to-date status of the reports?

\footnotetext{
${ }^{1}$ https://stars.aashe.org/institutions/participants-and-reports/

${ }^{2}$ http://www.eauc.org.uk/life/self-assessment_tool

${ }^{3} \mathrm{http}: / /$ www.greengownawards.org/categories-and-criteria\#SustainabilityReporting
} 
3. To what extend is sustainability curriculum provision covered in the reports?

The first and second research questions will result in an elementary analysis of university sustainability reports as an emerging practice among UK HEls. The third research question will explore the coverage of the sustainability curriculum provision by the reports as a means of achieving strategic integration of sustainability in the university curriculum. The paper is structured as follows: First, a literature review will describe previous research on sustainability curriculum baselining and sustainability reporting. Next, the study's design (sampling, data collection and data analysis) will be explained followed by the findings, a discussion of the findings and a conclusion.

\section{Literature review}

The literature review is divided in two sections: The first part describes attempts to audit sustainability curriculum provision while the second part explores the phenomenon of sustainability reporting in higher education.

\section{Sustainability curriculum provision audits}

To identify and record sustainability curriculum provision, certain universities in the UK have organised institutional curriculum reviews. These are a relative recent development and three recent baselines conducted at an institutional level are presented here. In 2015, Wyness and Sterling attempted to record sustainability curriculum provision at Plymouth University by distributing a review tool to academic leads, asking them to self-evaluate the degree of sustainability in their courses. For the construction of the tool and in order to define what constitutes sustainability related teaching and curriculum content, they followed Tilbury and Wortman's conceptualisation, which recommends thematic 'entry points' around the triple bottom line concept of sustainability (2008). The review included courses that address the environment, economy or equity aspects of sustainability in combination or separately. At the University of Bristol Tierney, Tweddell and Willmore (2015) perform a sustainability curriculum review, based on the catalogue of taught courses and Key Information Sets (KIS) on student experience provided by HEFCE. They use the UNESCO definition of ESD which covers four areas: socioeconomic justice, cultural diversity, human rights of future generations and restoration of the Earth's eco-systems (Tierney et al., 2015: 508). Olga Bloemen (2013) at the University of Edinburgh conducted a baselining of undergraduate courses ${ }^{4}$ related to Sustainability and Social Responsibility (SRS), a concept that encompasses social, economic and environmental themes. Looking at the three reviews, it can be noticed that each university adopted a different definition of sustainability and structured its audit accordingly. All three audits recognised that their basic aim was to inform and help shape the institution's sustainability strategy, the annual reflection of which is the sustainability report. The current study explores how annual sustainability reports record their institutions' sustainability curriculum provision.

\footnotetext{
${ }^{4}$ The scoping exercise was carried out at the Colleges of Humanities and Social Sciences (CHSS) and Science and Engineering (CSE)
} 
While the sustainability curriculum reviews mentioned above took place at an institutional level, ESD curriculum baselines have also been attempted at a national level. In Wales, $\mathrm{HEFCW}^{5}$ provided funding for universities to conduct audits of sustainability curriculum provision. The Sustainability Tool for Auditing University Curricula in Higher Education (STAUNCH) was selected by the Welsh authorities as the auditing method for that purpose (Glover et al 2011). This tool scores sustainability course content across three categories: economic, environmental and social. By adopting this triple bottom line model of sustainability, STAUNCH recognizes courses that address any of the three aspects in combination or separately. For instance, a module that focuses exclusively on Productivity or the Gross National Product would be recognised as a sustainability course. In contrast to this compartmentalizing treatment of sustainability, the authors of a sustainability curriculum review commissioned by HEFCE identify as sustainability curriculum courses the ones that combine at least two of the three aspects of the triple bottom line model (Policy Studies institute 2008: 88). '[Their] research project is using the following definition of sustainable development teaching: teaching that contains a significant element of work related to either or both of the natural environment and natural resources, PLUS a significant element of work related to either or both of economic or social issues' (Policy Studies institute, 2008: 89). This integrative 'plus' requirement echoes the 'at the same time' rule for designing sustainability curricula by the Forum for the Future, where it is expected that the environmental, economic and social aspects are simultaneously present in the design of sustainability courses (Parkin et al, 2004). The Welsh and English national audits described above were conducted using externally defined criteria which may not provide for the heterogeneous treatment of sustainability within each institution. The annual sustainability reports on the other hand are issued internally by each university and could provide a self-defined baseline of each institution's sustainability curriculum provision. An exploration of how UK universities' annual sustainability reports treat sustainability curriculum provision has not yet taken place and the current study aims to address this gap.

\section{University sustainability reporting}

Due to the relatively recent appearance of sustainability reporting in HE education, the research literature on the topic is rather limited (Beveridge et al 2015; Ceulemans et al 2015a; Ceulemans et al 2015b). Even less studies have explored how university sustainability reports cover sustainability curriculum provision. Of this limited research, five studies are highlighted below as they adopt an approach similar to the one adopted by the current study. In 2011 Lozano explored university sustainability reports that followed the GRI guidelines and found that only $6 \%$ of them contained references to educational dimensions. In the same year, Fonseca et al. analysed the sustainability reports of the 25 biggest Canadian universities to find that curriculum references exist in a quarter of the documents. In 2014 Stacey White explored sustainability plans in the US seeing $81 \%$ of them containing references to the curriculum. A year later, Lidstone et al (2015) analysed sustainability plans in Canadian universities to find that $86 \%$ contain goals within the domain of education. Finally, in 2016 Vaughter et al. explore sustainability plans in Canadian FHE institutions to see that only $12 \%$ contain references to the curriculum. What can be noticed is that in all five studies, sustainability curriculum is under-reported, since it never appears in $100 \%$ of the documents explored.

\footnotetext{
${ }^{5}$ Higher Education Funding Council for Wales
} 
And even though all studies explore the phenomenon of university sustainability reporting, each study analyses different types of documents. Lidstone et al. (2015) and White (2014) focus on sustainability plans with an institution wide coverage while Vaughter et al. (2016) explore both plans and policies (Table1). Fonseca et al (2011) and Lozano (2011) on the other hand analyse sustainability reports as stand-alone documents (Table1). The present study will on sustainability reports which adopt a whole institution approach and which have been published in the past five years (2012-2016). In doing so it will fill a geographic gap in the literature as this type of study has taken place in the US and Canada but not in the UK.

Table 1

Previous studies on sustainability reporting in higher education

\begin{tabular}{llllll}
\hline & Vaughter et al. & Lidstone et al. & White & Fonseca et al. & Lozano \\
& 2016 & 2015 & 2014 & 2011 & 2011 \\
\hline location & Canada & Canada & US & Canada & GRI worldwide \\
type of disclosure & plans \& policies & plans & plans & reports & reports \\
curriculum references & $12 \%$ & $86 \%$ & $81 \%$ & $25 \%$ & $6 \%$ \\
\hline
\end{tabular}

\section{Research design}

\section{Sampling}

As discussed above, studies on sustainability reporting at universities have been conducted in Canada and the US but not in the UK. The present study focuses on UK universities receiving public authority funding and being legally registered as a Higher Education Institution until November 2016. The alphabetic list of these can be found in Appendix A. In the text, university names have been substituted by their list number to neutralise reputational risk. The sample selection criteria are highlighted below:

1. The most recent, whole-institution sustainability reports issued by UK universities in the past five years (2012-2016) are included in the sample.

2. Disclosure documents with a future orientation, projected aims and targets like Sustainability Strategies, Policies, Missions, Visions and Plans are not part of this sample, which focuses on reports which record what has already been achieved.

3. Reporting documents that focus on a specific area like Environmental Management Systems (EMSs), Carbon Management Plans or Learning and Teaching Strategies are not included in the sample unless they adopt a whole institution approach.

4. It is acknowledged that multiple, alternative sustainability reporting venues exist like web-pages, newsletters, YouTube videos, twitter and Facebook updates. While the contribution of these alternative forms of reporting is valuable, they are beyond the scope of this study which attempts an elementary census of whole-institution sustainability reports as an emerging practice among UK HEIs.

\section{Data collection}

To identify the sustainability report of each university, the following steps were followed. The name of the university alongside the term 'sustainability' was entered in the Google search engine to locate the university's sustainability website, where links to the reports or to a 'policies' section were provided. In case this search did not yield any results, the institutional website was searched using the keywords 'sustainability / environmental' and 'report / statement'. 


\section{Data analysis}

The analysis of the reports proceeded in three phases, in order to address the three research questions. The first phase identified the existence (yes/no) of a sustainability report fulfilling the data collection criteria. The second phase explored the academic year the report was covering $(2012 / 13,2013 / 14,2014 / 15,2015 / 16)$ as it was hypothesized that providing timely and up-to-date information constitutes an optimal sustainability reporting practice. The third phase recorded the extent of formal curriculum provision coverage. This variable was operationalised using a coding frame as follows:

Code $1=$ No mention of sustainability curriculum in the report.

Code 2 = Single reference to sustainability curriculum not elaborated further.

Code $3=$ More than single reference to sustainability curriculum. Yet, references cover less than $50 \%$ of the institution's provision.

Code 4 = Extensive reference to sustainability curriculum covering the majority of the institution's provision (more than $50 \%$ of the courses covered).

This curriculum coverage coding was based on the STARS guideline 'AC1: Academic Courses', which recommends recording all an institution's 'sustainability courses' or 'courses that include sustainability' in order to achieve the highest reporting score (STARS, 2016: 32).

An exploratory content analysis was performed. At first each document was searched using the following keywords: curriculum, course, degree, module, education and teaching. Since keyword searches do not provide for alternative terminology, a subsequent close reading of each document was performed to more efficiently determine the coverage of sustainability curriculum according to the coding criteria. While the absence of reference (Code 1) and the existence of a single reference (Code 2) were easy to identify, determining whether the reports covered more (Code 4 ) or less (Code 3 ) of the sustainability courses on offer was more difficult to establish. To optimize the accuracy of the results under Codes 3 and 4, an inventory of all sustainability courses was created for each of the universities concerned based on catalogues of undergraduate and postgraduate taught sustainability courses. The unit of measurement was the individual undergraduate or postgraduate taught course fulfilling the criteria of a sustainability course as specified by STARS (STARS 2016: 36-37). If the report made references to less than $50 \%$ of these courses it was allocated Code 3 while if it covered more than $50 \%$ of the courses it was placed under Code 4.

\section{Findings}

The first phase of the analysis explored how many universities issued an annual sustainability report. Out of the 151 universities of the sample it was found that approximately a third $(n=46)$ have published a whole institution sustainability report in the past five years. The remaining universities either published one-dimensional reports (usually focusing on estates and operations) or recorded all sustainability performance information exclusively on their websites. A similar trend has been identified by Fonseca et al. (2011) who mention that only 7 of the 25 largest Canadian universities publish a sustainability 
report. A larger scale study by Beveridge et al. (2015) of all Canadian FHEls ${ }^{6}$ revealed that only $50 \%$ published a formal sustainability reporting document. The majority of the literature on the topic suggests that sustainability reporting in higher education is an uncommon practice (White 2014; Lozano 2011; Lidstone et al 2015).

The fact that sustainability reporting is an emerging area in higher education is further reflected in the diversity of the report labelling. In the current sample, the standard term 'Sustainability Report' was the title of five documents only, while a list of some of the heterogeneous titles encountered in the reports can be seen in Table 2. Hahn and Kühnen (2013) claim that it is the voluntary nature of sustainability reporting that has led organisations experimenting with how they disclose information and subsequently how they label the reports. This diversity in labelling has also been identified by Lidstone et al. (2015) in Canada and White (2014) in the US, where 14 different types of sustainability plans were encountered within a sample of 40 universities.

Table 2

Example of diverse sustainability report labelling

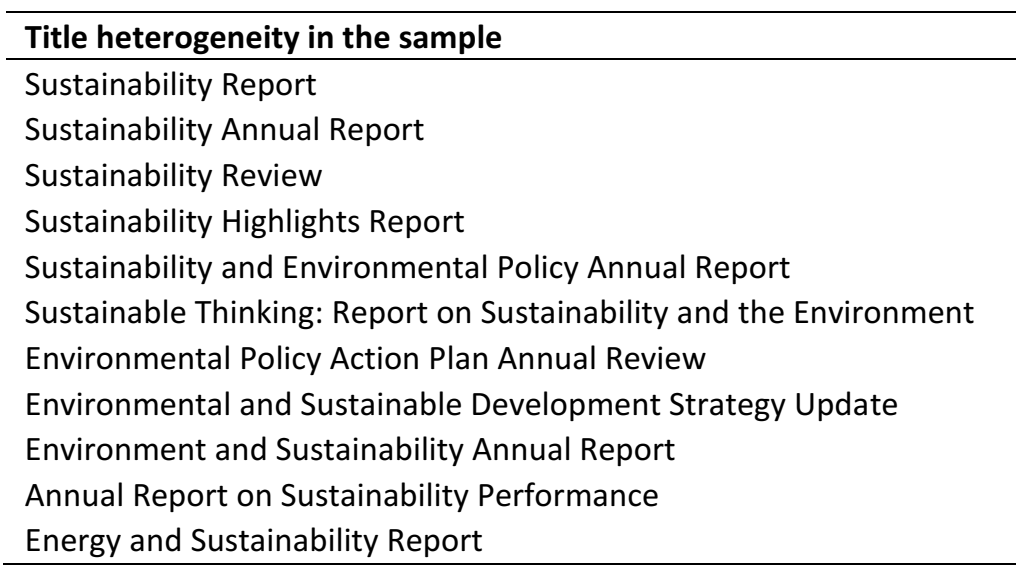

Due to this heterogeneity in titling, deciding which documents would be included in the sample did not depend solely on their title but also on content fulfilling the data collection criteria. For instance, university No4 issues an extensive document titled Environmental Management System Annual Report, which covers a variety of issues including Legislation and Annual Performance 2013/14. The Annual Performance 2013/14 part acts as wholeinstitution sustainability report and this document was included in the sample, despite the EMS title. Institution No88 split their Environmental and Sustainable Development Strategy Update in two parts, the first part Review of recent achievements describes what has been achieved so far while the second part presents Objectives and targets for further improvement. This document was included in the sample as the first part serves as a sustainability report and fulfils the data collection criteria. Institution No92 include their sustainability report in their general Annual Report while also providing a separate, standalone sustainability report. In such cases the more comprehensive of the two documents was included in the sample. University (No148) devotes a big section of their Sustainability Strategy to their past sustainability achievements across the institution. This document was also included as it fulfilled the data collection criteria, despite the fact that it was labelled a strategy.

\footnotetext{
${ }^{6}$ Further and Higher Education Institutions
} 
In the second phase of the analysis the up-to-date status of the reports was explored. It appears that only $44 \%$ of the reports were updated to the most recent academic year 20152016, with 39\% covering the previous year (2014-2015) and 4\% dating back to 2012-13 (Table 3).

Table 3

The most recent academic year the reports cover

\begin{tabular}{ll}
\hline Academic year & Percentage of reports covering each academic year \\
\hline $2012-13$ & $4 \%$ \\
$2013-14$ & $13 \%$ \\
$2014-15$ & $39 \%$ \\
$2015-16$ & $44 \%$ \\
\hline
\end{tabular}

These findings echo the findings of Lock and Seele (2016) on CSR reporting in Europe, where similar patterns in the update status of the reports were identified. This diversity is attributed to companies having different publication routines, with some publishing a report every year while others bi- or triennially (Lock and Seele, 2016: 189). Timeliness of the reported content is seen as contributing to the quality of the reports.

The third phase of the analysis identified the sustainability curriculum provision coverage achieved by the reports (Figure 1). It was found that $37 \%$ of the reports the sample contain comprehensive coverage of the university's sustainability curriculum provision (Code 4). Broad reference to curriculum without covering the majority of the sustainability courses on offer is identified in $30 \%$ of the reports (Code 3 ) while $22 \%$ of the documents adopt a highlight approach (Code 2). In reports with single reference to sustainability curriculum, phrases similar to the following are to be encountered: 'embed sustainability across the curriculum'. The remaining $11 \%$ of the reports make no reference to the curriculum, even though they adopt a whole institution approach and address other aspects of sustainability, like research.

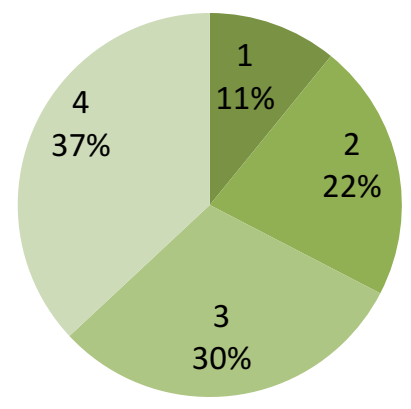

Fig. 1 Sustainability curriculum provision coverage in university sustainability reports

Having $33 \%$ of the whole institution sustainability reports containing no or little reference, compares favourably with previous studies' results, where it is seen that references to sustainability curriculum are inadequate. Fonseca et al. (2011) found that references to 
sustainability incorporation in the curriculum were 'restricted and elusive' (35). Vaughter et al. (2016) noted that discussions of sustainability in the curriculum were vaguely operationalised in their sample. Similarly, Lidstone et al. (2015) reported that there is little discussion on how sustainability is to be integrated in the curriculum or what type of learning outcomes are to be achieved. Thus, the quantification and operationalisation of sustainability curriculum provision in the reports is seen as inadequate across previous studies.

It may be of interest to note that in the current sample the majority of reports, coming from institutions with a Responsible Futures accreditation appear to cover sustainability curriculum provision comprehensively (Levels 3 or 4). Responsible Futures promotes the integration of sustainability in the curriculum of tertiary education institutions and two of its mandatory criteria is the inclusion of sustainability in the institution's strategy and the creation of a baseline are the institution's sustainability curriculum ${ }^{7}$. Thus there seems to be reciprocity between the existence of a Responsible Futures accreditation and comprehensive coverage of sustainability curriculum in those institutions' reports.

A similar trend can be observed with institutions participating in the UI Green Metric, a global ranking of universities according to their sustainability performance. One of the UI Green Metric criteria asks for the ratio of their sustainability curriculum courses compared to the number of total courses ${ }^{8}$. The reports of all institutions that had participated in the $\mathrm{UI}$ Green Metric provided wide coverage of their sustainability curriculum provision (Levels 3 or 4). A positive correlation appears to exist between comprehensive sustainability curriculum coverage and participation in a sustainability assessment system which entails a sustainability curriculum baselining criterion. This finding further supports previous literature on how HE sustainability assessment standards systematize and enhance university sustainability performance (Fischer et al 2015; Lambrechts 2015; Ramos and Pires 2013, Disterheft et al 2012).

\section{Discussion}

Based on the above findings certain issues are highlighted here for discussion. Comprehensive sustainability curriculum coverage being linked with participation in a sustainability assessment standard has been identified by previous research. Looking back at the studies of the Literature Review section (Table 1), it can be seen that studies which explore STARS created reports (Vaughter et al 2016; Lidstone et al 2015; White 2014) record greater percentages of sustainability curriculum coverage compared to studies of nonSTARS reports (Fonseca et al 2011; Lozano 2011). This might be explained by the fact that STARS provides a standardised procedure for reporting on sustainability, through its Academic Courses (AC1) criterion which encourages institutions to record all taught curriculum related to sustainability (STARS 2016: 31). Standardisation of information is seen as positively contributing to report quality and credibility (Lock and Seele 2016). Moreover, if the reports do not cover the whole spectrum of sustainability curriculum provision, they are insufficient as tools for informing and influencing decision making (Fonseca et al 2011).

\footnotetext{
http://sustainability.unioncloud.org/responsible-futures/about/partnerships

${ }^{8}$ http://greenmetric.ui.ac.id/criterian-indicator/
} 
The existence of a comprehensive, whole-institution sustainability report as a method of inhouse benchmarking of sustainability curriculum provision might help universities better communicate and promote their ESD curriculum provision to various stakeholders. Moreover, comprehensive coverage of sustainability curriculum provision by the annual sustainability report can help institutions meet circumstances unique to the UK HE sector, like the People and Planet University League, the QAA reviews and in the case of Wales government regulatory requirements.

A limitation of the study stems from the fact that it does not explore web-based sustainability reporting. Certain universities not only maintain well informed and comprehensive sustainability websites but also comprehensively showcase their undergraduate and postgraduate sustainability courses in some cases even categorised by department. Web-based reporting bears great potential (Dade and Hassenzahl 2013) and might become the norm in the future which turns this limitation into a recommendation for future research. Having explored a single aspect of sustainability reporting does not allow generalizability of the findings to HE sustainability reporting more broadly. This justifies the misalignment between the Existence (yes/no) criteria and the Environmental Reporting Total (yes/no) included in the Environmental Information by HE Provider dataset by the Higher Education Statistics Agency (HESA) ${ }^{9}$.

\section{Conclusion}

The current census of whole-institution sustainability reports in the UK HE sector contributes to the under-researched area of university sustainability reporting. Since this type of study has taken place in the US and Canada but not in the UK, this research covers a geographical gap in the literature as well. A third of UK universities $(n=46)$ issue a whole institution sustainability report and of these $37 \%$ comprehensively cover their institution's sustainability curriculum provision in their documents. According to the STARS reporting guidelines recording all an institution's sustainability courses constitutes optimal practice in university sustainability reporting. The findings are consistent with previous research, where sustainability curriculum is seen as not adequately covered by the universities' sustainability reporting documents. Since only a single type of university sustainability disclosure was analysed, the results cannot be generalised to HE sustainability reporting more broadly. As highlighted in the Discussion section, the study does not address web-based reporting and this area provides fertile ground for future research.

According to Evans et al. there are 0.5 million students studying sustainability related courses in the UK who could offer 42.808 years of research time per year $(2015: 1)$. Recording and promoting these courses across multiple channels might help move the sustainability agenda forward and expose this untapped powerful resource within universities. In the UK HE sector, comprehensively reporting on the institution's sustainability curriculum achievements can be further aligned with the Teaching Excellence Framework (TEF), which under its Student Outcomes and Learning Gain (SO) indicator specifies equipping graduates with attributes that allow them to make 'a strong contribution to society, economy and the environment' (TEF 2016: 23). There is thus a demand to equip students with sustainability skills. Part of institutions' response to this demand can be the

\footnotetext{
${ }^{9}$ https://www.hesa.ac.uk/data-and-analysis
} 
comprehensive reporting of the institutions' annual sustainability curriculum provision. It is hoped that the findings of this study will encourage more comprehensive coverage of ESD curriculum provision in universities' whole-institution sustainability reports.

\section{References}

Beveridge D, McKenzie M, Vaughter P, Wright T (2015) Sustainability in Canadian postsecondary institutions. The inter-relationships among sustainability initiatives and geographic and educational characteristics. International Journal of Sustainability in Higher Education 16 (5): 611-638. doi: 10.1108/IJSHE-03-2014-0048

Bloemen, O (2013) Learning for change: Social responsibility and sustainability courses at the University of Edinburgh 2012-2013. Institute for Academic Development. University of Edinburgh, Edinburgh.

http://www.docs.hss.ed.ac.uk/iad/Learning teaching/Academic teaching/Resources/Sustai nability/SRS in UG Courses Full Report.pdf Accessed 20 Jan 2017

Ceulemans K, Lozano R, del Mar Alonso-Almeida M (2015a) Sustainability Reporting in Higher Education: Interconnecting the Reporting Process and Organisational Change Management for Sustainability. Sustainability 7(7): 8881-8903. doi:10.3390/su7078881

Ceulemans K, Molderez I, Van Liedekerke L (2015b) Sustainability reporting in higher education: a comprehensive review of the recent literature and paths for further research. Journal of Cleaner Production 106: 127-143. doi: 10.1016/j.jclepro.2014.09.052

Dade A, Hassenzahl D.M (2013) Communicating sustainability: A content analysis of website communications in the United States. International Journal of Sustainability in Higher Education 14 (3): 254-263.

Disterheft A, Caeiro S, Ramos M R, Azeiteiro U (2012) Environmental management systems (EMS) implementation processes and practices in European Higher Education Institutions: top-down versus participatory approaches. Journal of Cleaner Production 31: 80-90.

Drayson R, Taylor C (2015) The student voice: experiences of student engagement in education for sustainable development. In: Filho W, Brandli W, Kuznetsova O, Paço A (eds) Integrative Approaches to Sustainable Development at University Level, World Sustainability Series. doi: 10.1007/978-3-319-10690-8_43

Evans J, Jones R, Karvonen A, Millard L, Wendler J (2015) Living labs and co-production: university campuses as platforms for sustainability science. Current Opinion in Environmental Sustainability 16: 1-6. doi: 10.1016/j.cosust.2015.06.005

Fischer D, Jenssen S, Tappeser V (2015) Getting an empirical hold of the sustainable university: a comparative analysis of evaluation frameworks across 12 contemporary 
sustainability assessment tools. Assessment and Evaluation in Higher Education 41 (1): 1-16. doi: 10.1080/02602938.2015.1043234

Fonseca A, Macdonald A, Dandy E, Valenti P (2011) The state of sustainability reporting at Canadian universities. International Journal of Sustainability in Higher Education 12 (1): 2240. doi: $10.1108 / 14676371111098285$.

Glover A, Peters C, Haslett S K (2011) Education for sustainable development and global citizenship: An evaluation of the validity of the STAUNCH auditing tool. International Journal of Sustainability in Higher Education 12 (2): 125-144. doi: 10.1108/14676371111118192

GRI (2015) Sustainability and Reporting Trends in 2025; Preparing for the Future. The Netherlands: Global Reporting Initiative.

https://www.globalreporting.org/resourcelibrary/Sustainability-and-Reporting-Trends-in2025-2.pdf Accessed 30 Jan 2017

Hahn R, Kühnen M (2013) Determinants of sustainability reporting: a review of results, trends, theory, and opportunities in an expanding field of research. Journal of Cleaner Production 59: 5-21. doi: 10.1016/j.jclepro.2013.07.005

HEFCE (2014) Sustainable development in higher education: HEFCE's role to date and a framework for its future actions. HEFCE. http://www.hefce.ac.uk/pubs/year/2014/201430/ Accessed 30 Jan 2017

KPMG (2012) Sustainability Reporting Systems: A Market Review. The Netherlands: KPMG Advisory N.V. https://assets.kpmg.com/content/dam/kpmg/pdf/2012/08/S CG 5e.pdf Accessed 15 Jan 2017

Lambrechts W (2015) The contribution of sustainability assessment to policy development in higher education. Assessment and Evaluation in Higher Education 40 (6), 776-795. doi: 10.1080/02602938.2015.1040719

Lidstone L, Wright T, Sherren K (2015) An analysis of Canadian STARS-rated higher education sustainability policies. Environment, Development and Sustainability 17(2), 259-278. doi:10.1007/s10668-014-9598-6

Lock I, Seele P (2016) The credibility of CSR (corporate social responsibility) reports in Europe. Evidence from a quantitative content analysis in 11 countries. Journal of Cleaner Production 122, 186-200. doi: 10.1016/j.jclepro.2016.02.060

Lozano R (2011) The state of sustainability reporting in universities. International Journal of Sustainability in Higher Education 12(1), 67-78. doi: 10.1108/14676371111098311.

Parkin S, Johnston A, Buckland H, Brookes F, White E (2004) Learning and Skills for Sustainable Development: Developing a Sustainability Literate Society. Guidance for Higher Education Institutions. Forum for the Future, London. 
https://www.forumforthefuture.org/sites/default/files/project/downloads/learningandskills .pdf Accessed 30 Jan 2017

Policy Studies Institute (2008) HEFCE Strategic Review of Sustainable Development in Higher Education in England. PA Consulting Group and the Centre for Research in Education and the Environment, University of Bath. www.eauc.org.uk/file uploads/hefce review.pdf Accessed 30 Jan 2017

PwC (2016) Good Practices in Sustainability Reporting: Building Public Trust Awards. PricewaterhouseCoopers LLP. http://www.pwc.co.uk/assets/pdf/good-practices-insustainability-reporting-2015.pdf Accessed 30 Jan 2017

QAA (2014) Education for Sustainable Development: Guidance for UK Higher Education Providers. http://www.qaa.ac.uk/en/Publications/Documents/Education-sustainabledevelopment-Guidance-June-14.pdf Accessed 30 Jan 2017

Ramos T, Pires S M (2013) Sustainability assessment: the role of indicators. In: Caeiro S, Filho W, Jabbour C, Azeiteiro $U$ (eds) Sustainability assessment tools in higher education institutions; mapping trends and good practices around the world. Springer, London. pp 81-99

Ryan A, Cotton D (2013) Times of change: shifting pedagogy and curricula for future sustainability. In: Sterling S, Maxey L, Luna H (eds) The Sustainable University. Routledge, Oxon. pp 151-167

STARS (2016) STARS Technical Manual; Version 2.1. Administrative Update One. AASHE. http://www.aashe.org/files/documents/STARS/2.0/stars 2.1 technical manual administrative update two.pdf Accessed 30 Jan 2017

Sterling S (2012) The Future Fit Framework; An Introductory Guide to Teaching and Learning for Sustainability in HE. Higher Education Academy.

https://www.heacademy.ac.uk/system/files/future fit 270412 1435.pdf Accessed 10 Jan 2017

TEF (2016). Teaching Excellence Framework Year Two Additional Guidance. HEFCE. http://www.hefce.ac.uk/media/HEFCE,2014/Content/Pubs/2016/201632/HEFCE2016 32.p df Accessed 15 Jan 2017

Tilbury D, Ryan A (2011) Embedding sustainability in the DNA of the University. International Research Institute in Sustainability, University of Gloucestershire. https://www.academia.edu/1409492/Embedding Sustainability within the DNA of Unive rsities Accessed 10 Jan 2017

Tilbury D, Wortman D (2008) Education for Sustainability in Higher Education: reflections along the journey. Journal for Planning in higher Education, Society for College and University Planning 36(4):5-16. 
Tierney A, Tweddell H, Willmore C (2015) Measuring education for sustainable development. International Journal of Sustainability in Higher Education 16 (4): 507-522. doi:

10.1108/IJSHE-07-2013-0083

Vaughter $P$, McKenzie $M$, Lidstone L, Wright T (2016) Campus sustainability governance in Canada. International Journal of Sustainability in Higher Education 17(1): 16-39.

White S (2014) Campus sustainability plans in the United States: where, what, and how to evaluate. International Journal of Sustainability in Higher Education 3(3): 203-220. doi: $10.1108 / 14676371111098320$

Wyness L, Sterling S (2015) Reviewing the incidence and status of sustainability in degree programmes at Plymouth university. International Journal of Sustainability in Higher Education 16 (2): 237-250. doi: 10.1108/IJSHE-09-2013-0112 


\title{
Appendix A. UK universities in the sample
}

\author{
1. Aberystwyth University \\ 2. Anglia Ruskin University \\ 3. Aston University \\ 4. Bangor University \\ 5. Bath Spa University \\ 6. Birmingham City University \\ 7. Birbeck, University of London \\ 8. Bishop Grosseteste University \\ 9. Bournemouth University \\ 10. Brunel University London \\ 11. Buckinghamshire New University \\ 12. Canterbury Christ Church University \\ 13. Cardiff Metropolitan University \\ 14. Cardiff University \\ 15. Courtauld Institute of Art \\ 16. Coventry University \\ 17. Cranfield University \\ 18. De Montfort University \\ 19. Edge Hill University \\ 20. Edinburgh Napier University \\ 21. Falmouth University \\ 22. Glasgow Caledonian University \\ 23. Glasgow School of Art \\ 24. Glyndŵr University \\ 25. Goldsmiths University of London \\ 26. Guildhall School of Music and Drama \\ 27. Harper Adams University \\ 28. Heriot-Watt University \\ 29. Heythrop College \\ 30. Imperial College London \\ 31. King's College London \\ 32. Kingston University \\ 33. Leeds Beckett University \\ 34. Leeds Trinity University \\ 35. Liverpool Hope University \\ 36. Liverpool John Moores University \\ 37. London Business School \\ 38. London Metropolitan University \\ 39. London School of Economics and Political Science \\ 40. London School of Hygiene and Tropical Medicine \\ 41. London South Bank University \\ 42. Loughborough University \\ 43. Middlesex University \\ 44. Newman University \\ 45. Northumbria University \\ 46. Norwich University of the Arts \\ 47. Oxford Brookes University \\ 48. Queen Margaret University, Edinburgh \\ 49. Queen Mary University of London \\ 50. Ravensbourne \\ 51. Roehampton University \\ 52. Rose Bruford College \\ 53. Royal Academy of Music \\ 54. Royal Agricultural University \\ 55. Royal College of Art \\ 56. Royal College of Music \\ 57. Royal Conservatoire of Scotland \\ 58. Royal Holloway \\ 59. Royal Northern College of Music \\ 60. Sheffield Hallam University \\ 61. Southampton Solent University \\ 62. St George's, University of London
}

63. St Mary's University College, Belfast 
64. St Mary's University, Twickenham

65. Staffordshire University

66. Stranmillis University College

67. Swansea University

68. The Arts University Bournemouth

69. The City University

70. The Institute of Cancer Research

71. The Manchester Metropolitan University

72. The Nottingham Trent University

73. The Open University

74. The Queen's University of Belfast

75. The Robert Gordon University

76. The Central School of Speech and Drama

77. The Royal Veterinary College

78. The School of Oriental and African Studies

79. The University of Aberdeen

80. The University of Bath

81. The University of Birmingham

82. The University of Bolton

83. The University of Bradford

84. The University of Brighton

85. The University of Bristol

86. The University of Cambridge

87. The University of Central Lancashire

88. The University of Chichester

89. The University of Dundee

90. The University of East Anglia

91. The University of East London

92. The University of Edinburgh

93. The University of Essex

94. The University of Exeter

95. The University of Glasgow

96. The University of Greenwich

97. The University of Huddersfield

98. The University of Hull

99. The University of Keele

100. The University of Kent

101. The University of Lancaster

102. The University of Leeds

103. The University of Leicester

104. The University of Lincoln

105. The University of Liverpool

106. The University of Manchester

107. The University of Northampton

108. The University of Oxford

109. The University of Portsmouth

110. The University of Reading

111. The University of Salford

112. The University of Sheffield

113. The University of Southampton

114. The University of St Andrews

115. The University of Stirling

116. The University of Strathclyde

117. The University of Sunderland

118. The University of Surrey

119. The University of Sussex

120. The University of the West of Scotland

121. The University of Warwick

122. The University of West London

123. The University of Westminster

124. The University of Winchester

125. The University of Wolverhampton

126. The University of York

127. Trinity Laban Conservatoire of Music and Dance

128. University College Birmingham

129. University College London

130. University for the Creative Arts

131. University of Abertay Dundee

132. University of Bedfordshire

133. University of Chester

134. University of Cumbria

135. University of Derby

136. University of Durham

137. University of Gloucestershire

138. University of Hertfordshire

139. University of Newcastle

140. University of Nottingham

141. University of Plymouth

142. University of South Wales

143. University of St Mark and St John

144. University of Suffolk 
145. University of the Arts, London

146. University of the West of England, Bristol

147. University of Ulster

148. University of Wales Trinity Saint David

149. University of Worcester

150. Writtle University College

151. York St John University 